\title{
KETERLIBATAN MAHKAMAH KONSTITUSI DALAM POLITIK LEGISLASI NASIONAL
}

(The Engagement of Constitutional Court in Political Process of National Legislation)

\author{
Bisariyadi \\ Mahkamah Konstitusi Republik Indonesia \\ Jl. Medan Merdeka Barat No. 6, Jakarta Pusat, 10110 \\ e-mail: bee.sars@gmail.com
}

Naskah diterima: 17 September 2015; revisi: 24 November 2015; disetujui: 2 Desember 2015

\begin{abstract}
Abstrak
Politik legislasi tidak semata berkutat di parlemen, prinsip pemisahan kekuasaan tidak lagi dimaknai secara kaku. Kecenderungan lembaga peradilan untuk terlibat dalam politik legislasi semakin besar dengan diadopsinya kewenangan judicial review. Beragam produk legislasi yang menyangkut hajat hidup orang banyak diuji oleh Mahkamah Konstitusi. Penelitian ini bermaksud mencari bagaimana legitimasi konseptual atas keterlibatan lembaga peradilan dalam politik legislasi dengan melihat pada konsep judicialisation of politics melalui putusan-putusan peradilan di MK. Oleh sebab itu, penting untuk menganalisa putusan-putusan MK yang bernuansa politis dan mampu mempengaruhi politik legislasi nasional. Dengan menggunakan pendekatan nornatif, penelitian ini menunjukkan bahwa dengan diadopsinya kewenangan pengujian UU terhadap UUD, MK telah menembus batas prinsip pemisahan kekuasaan. MK juga menjalankan fungsi legislasi dengan bertindak sebagai positive legislator. Legitimasi konseptual juga telah ditawarkan oleh para ahli hukum dan politik dengan merumuskan konsep judicialisation of politics. Dimasa mendatang, lembaga peradilan akan semakin cenderung terlibat dalam perkara-perkara menyangkut proses pengambilan kebijakan yang menyangkut kepentingan orang banyak dimana awalnya proses itu merupakan kewenangan eksklusif dari legislatif.
\end{abstract}

Kata Kunci: pengujian undang-undang, mahkamah konstitusi, politik legislasi

Abstract
Political process of legislation is not only struggling in the parliament, the principle of separation of powers is no longer interpreted rigidly. The tendency of courts to engage political process of legislation are increasing with the adoption of a judicial review authority. Several different product of legislation concerning the lives of many people had been tested by the Constitutional Court. This study intends to find out how the conceptual legitimacy of the judiciary is involved in political process of legislation set out from the judicialisation of politics concept through decision of the Constitutional court. Therefore, it is important to analyze decisions made by The Constitutional Court with some political issues and able to influence political process of the legislation. Using normative approach, this study shows with adopting the power to examine Law against the Constitution, the Constitutional Court has been through the boundaries the principle of separation of powers. The Court also carry out its legislative function by acting as a positive legislator. Conceptual legitimacy has been offered by the legal and political experts to formulate the judicialisation of politics concept. In the future, the judiciary will be more likely to engage in policy making concerning the interests of the people which initially is exclusive authority of the legislative.

Keywords: judicial review, the constitutional court, political process of legislation 


\section{A. Pendahuluan}

Legislasi merupakan sebuah kata serapan dari bahasa Inggris "legislation" yang diterjemahkan sebagai sebuah proses pembentukan peraturan perundang-undangan atau dapat juga diartikan sebagai hukum atau perundang-undangan itu sendiri. ${ }^{1}$ Penggunaan kata "legislasi" seringkali digunakan secara bebas untuk merujuk pada peraturan perundang-undangan. Padahal, yang disebut peraturan perundang-undangan di Indonesia memiliki jenis dan hirarki, dimulai dari Undang-Undang Dasar hingga Peraturan Daerah. Sejatinya, pemaknaan kata "legislasi" memiliki ruang lingkup yang lebih sempit. Kata "legislasi" hanya dapat disematkan untuk pembuatan peraturan perundang-undangan yang melibatkan parlemen yaitu Dewan Perwakilan Rakyat (DPR) atau Dewan Perwakilan Rakyat Daerah (DPRD) sebagai pihak yang memegang kewenangan untuk membuatnya. Kata "legislasi" adalah dimaksudkan untuk merujuk pada produk hukum yang dihasilkan oleh DPR atau DPRD yaitu Undang-Undang (UU) ditingkat pusat atau Peraturan Daerah (Perda) ditingkat daerah.

Di Indonesia, legislasi berada dalam ranah kewenangan parlemen. ${ }^{2}$ Ditingkat nasional, legislasi merupakan salah satu fungsi DPR disamping fungsi lainnya sebagaimana diatur pada Pasal 20A ayat (1) UUD 1945 yang menyatakan "Dewan Perwakilan Rakyat memiliki fungsi legislasi, fungsi anggaran dan fungsi pengawasan". Pengaturan demikian merupakan konsekuensi dari perubahan UUD 1945 yang menggeser kekuasaan membentuk undangundang dari tangan Presiden kepada DPR. Akan tetapi, dalam penelitian Saldi Isra pergeseran kekuasaan legislatif tidak berdampak pada menguatnya peran legislasi yang dihasilkan oleh DPR, eksekutif (Presiden) masih mendominasi pembuatan undang-undang. ${ }^{3}$ Jimly Asshiddiqie mengamati bahwa sesungguhnya terdapat kecenderungan yang terjadi di berbagai negara dimana fungsi legislatif dianggap tidak lebih penting dibanding fungsi pengawasan, karena pembuatan undang-undang merupakan fungsi yang bersifat teknis sedangkan fungsi pengawasan lebih bernuansa politis. ${ }^{4}$

Ditingkat daerah, fungsi legislasi dijalankan oleh parlemen daerah, yaitu DPRD Provinsi dan DPRD Kabupaten/Kota dengan menghasilkan Peraturan Daerah. Pembentukan legislasi daerah merupakan mandat konstitusional yang diatur dalam Pasal 18 ayat (6) UUD 1945 dimana dinyatakan bahwa "[p]emerintahan daerah berhak menetapkan peraturan daerah dan peraturan-peraturan lain untuk melaksanakan otonomi dan tugas pembantuan". Titik berat pembentukan legislasi daerah diletakkan pada 
pundak perlemen daerah yaitu DPRD Provinsi ${ }^{5}$ dan DPRD Kabupaten/Kota6.

Penyusunan legislasi merupakan sebuah proses politik. Pembahasan legislasi merupakan proses yang melibatkan banyak kepentingankepentingan yang perlu diakomodasi. Anggota parlemen yang juga merupakan anggota partai politik memiliki tugas untuk menyampaikan aspirasi konstituennya agar dapat tertuang dalam produk legislasi. Tidak hanya kepentingan-kepentingan yang diwakili oleh masing-masing anggota parlemen namun dalam proses penyusunan hingga pengesahan, terdapat lembaga-lembaga negara lain yang terlibat dalam proses legislasi. Ditingkat nasional, ada Dewan Perwakilan Daerah (DPD) salah satunya. DPD diberikan kewenangan secara konstitusional untuk terlibat dalam proses penyusunan legislasi bersama dengan DPR dengan mengajukan serta ikut membahas Rancangan Undang-Undang (RUU) yang berkaitan dengan kebijakan otonomi daerah.' Selain DPD, Presiden juga memiliki hak inisiatif untuk mengajukan RUU kepada DPR. ${ }^{8}$ Ditambah lagi, peran Presiden dalam proses legislasi juga sedemikian besar terutama dalam hal mencapai kesepakatan suatu produk legislasi. Produk legislasi baru dapat menjadi undang-undang bila telah disetujui bersama oleh DPR dan Presiden. ${ }^{9}$
Persetujuan berbeda dengan pengesahan. Dalam hal pengesahan, Presiden tidak memiliki kewenangan sebesar persetujuan. Syarat adanya persetujuan bersama antara DPR dan Presiden dalam pembahasan RUU adalah hal yang mutlak, bila salah satu pihak tidak setuju maka RUU tidak dapat diajukan lagi pada masa sidang DPR yang sama. ${ }^{10}$ Berbeda halnya dengan pengesahan. Konstitusi memandatkan Presiden untuk mengesahkan RUU yang telah mendapat persetujuan bersama. ${ }^{11}$ Namun bila Presiden tidak mengesahkan RUU tersebut dalam jangka waktu 30 hari sejak RUU memperoleh persetujuan bersama maka UU tersebut tetap sah dan wajib diundangkan dalam lembaran negara. ${ }^{12}$

Diadopsinya kewenangan judicial review menambah keterlibatan lembaga negara dalam proses legislasi. Produk legislasi yang dihasilkan oleh parlemen dimungkinkan untuk diuji oleh lembaga peradilan bila aturan legislasimelanggar hak-hak warga negara. Lembaga peradilan disini termasuk didalamnya Mahkamah Konstitusi (MK) dan Mahkamah Agung (MA). Baik MK maupun MA diberikan kewenangan secara konstitusional untuk menguji peraturan perundang-undangan (judicial review). MK diberikan mandat untuk menguji UU terhadap UUD $^{13}$ sedangkan MA berwenang untuk menguji peraturan perundang-undangan dibawah UU terhadap UU. ${ }^{14}$ Dengan demikian,

\footnotetext{
Pasal 96 ayat (1) UU nomor 23 tahun 2014 tentang Pemerintahan Daerah yang menyebutkan "DPRD provinsi mempunyai fungsi: a. Pembentukan Perda provinsi; b ..."

6 Pasal 149 ayat (1) UU nomor 23 tahun 2014 tentang Pemerintahan Daerah yang menyatakan "DPRD kabupaten/ kota mempunyai fungsi: a. Pembentukan Perda kabupaten/kota; ..."

Pasal 22D ayat (1) dan (2) UUD 1945

Pasal 5 ayat (1) UUD 1945

Pasal 20 ayat (2) UUD 1945

Pasal 20 ayat (3) UUD 1945

Pasal 20 ayat (4) UUD 1945

Pasal 24C ayat (1) UUD 1945

Pasal 24A ayat (1) UUD 1945

14 http://www.bappenas.go.id/index.php/download_file/view/9567/1781/., (diakses 26 februari 2015) ${ }^{9}$ Ibid, hlm. 42.
} 
MK berwenang untuk menguji produk legislasi nasional dalam bentuk UU sedangkan MA berhak untuk menguji produk legislasi daerah dalam bentuk Perda.

Penelitian ini bermaksud untuk melihat keterlibatan lembaga peradilan dalam politik legislasi. Fenomena ini merupakan sebuah anomali. Lembaga peradilan diidentikkan dengan hukum yang biasa dipisahkan dari proses politik. Namun dengan diadopsinya judicial review, hukum menjadi berkelindan dalam proses politik. Sebenarnya, bagaimana hubungan antara hukum dan politik dan apakah ada justifikasi teoritis yang menangkap fenomena ini. Bagian pertama pembahasan dalam tulisan ini akan mengulas permasalahan tersebut dengan menggunakan pendekatan konsep judicialisation of politics.

Kemudian, bagian kedua akan melihat bagaimana konsep tersebut terterapkan dalam praktek peradilan di Indonesia melalui putusan-putusan peradilan di MK. Bagian kedua ini akan dibatasi dengan memotret pada praktek judicial review di MK karena beberapa alasan. Pertama, keterlibatan MA dalam politik legislasi daerah dapat dikatakan rendah. Indikasinya adalah jumlah perkara judicial review perkara yang diperiksa MA dari tahun ke tahun sangatlah sedikit. Pada tahun 2013 MA menerima perkara hak uji materiil (judicial review) sebanyak 76 perkara. Dari jumlah tersebut, perkara yang menyangkut judicial review Perda adalah 11 perkara. ${ }^{15}$ Jumlah penerimaan perkara hak uji materiil Perda mengalami peningkatan pada tahun 2014 sebanyak 17 perkara dari keseluruhan perkara hak uji materiil yang diterima MA sebanyak 83 perkara. Namun, jumlah perkara judicial review Perda yang diterima MA tidaklah signifikan dibanding dengan jumlah daerah Provinsi dan Kabupaten/Kota yang ada di Indonesia. Letak persoalan rendahnya perkara judicial review Perda yang diterima oleh MA, dalam pengamatan Pusat Studi Hukum dan Kebijakan (PSHK) disebabkan mekanisme prosedur pengajuan dan persidangan di MA menyulitkan masyarakat seperti adanya pembatasan waktu pengajuan Perda, pembebanan biaya pendaftaran dan penanganan perkara, jangka waktu pemeriksaan dan transparansi dalam pemeriksaan permohonan. ${ }^{16}$ Persoalan ini kemudian menjadi elemen penghambat minat pemohon untuk mengajukan judicial review Perda. Kedua, pengaruh kehadiran MK dalam kancah ketatanegaraan terutama dalam ranah politik legislasi sangatlah diperhitungkan. Beberapa putusan yang dikeluarkan MK mempengaruhi kehidupan berbangsa dan bernegara. Lingkup putusan MK itu tidak hanya dalam kancah lokal namun juga nasional. Oleh sebab itu, penting untuk menganalisa putusanputusan MK yang bernuansa politis dan mampu mempengaruhi politik legislasi nasional.

\section{B. Metode Penelitian}

Pendekatanyang digunakan dalam penelitian ini adalah pendekatan normatif dengan menitikberatkan pada studi kepustakaan yang menggunakan data-data sekunder. Beberapa literatur hukum akan digunakan sebagai sumber kepustakaan, terutama dalam mengkaji

15 Mahkamah Agung, Laporan Tahunan Mahkamah Agung Republik Indonesia 2013, hlm. 41.

16 M. Nur Solikin, Ronald Rofiandri, dkk, "Laporan Kajian tentang Implementasi Pengawasan Perda oleh Pemerintah dan Mahkamah Agung", (Pusat Studi Hukum dan Kebijakan Indonesia: 2011), hlm. 68. 
konsep dan teori. Sebagaimana disebutkan diatas, maka bagian pertama tulisan ini akan lebih mengedepankan pada kajian teoritis dan konseptual. Hal ini dilakukan untuk mencaritahu hubungan antara hukum dan politik serta apa yang dimaksudkan dengan judicialisation of politics. Pendekatan konsep judicialisation of politics adalah untuk menjawab tema besar yang diusung penelitian ini mengenai keterlibatan lembaga peradilan dalam politik legislasi.

Kemudian, bagian kedua pembahasan penelitian ini mencoba memotret praktek keterlibatan Mahkamah Konstitusi dalam politik legislasi nasional melalui kajian atas putusanputusan yang pernah dikeluarkan MK. Oleh karenanya, pendekatan yang dilakukan dalam membahas persoalan ini adalah pendekatan kasus (case approach) dan pendekatan perundang-undangan (statute approach). Yang dimaksud dengan pendekatan kasus adalah perkara-perkara pengujian UU terhadap UUD yang ditangani MK sedangkan pendekatan perundang-undangan adalah melihat norma dalam UU yang diuji oleh MK.

\section{Pembahasan}

\section{Mencari Hubungan Hukum dan Politik}

Para pakar senantiasa mempertanyakan hubungan antara hukum dan politik, bahkan cenderung berupaya untuk memisahkan hukum dan politik secara diametral. Namun demikian, upaya pemisahan hukum dan politik secara diametral selalu berujung pada ketidakmungkinan pemisahan hukum dan politik. ${ }^{17}$ Mahfud menjelaskan bahwa perbedaan pola hubungan politik dan hukum disebabkan oleh perbedaan cara para ahli memandang kedua subsistem kemasyarakatan tersebut. Para ahli memandang hukum baik dari sudut das sein (keharusan) atau pun sudut das sollen (kenyataan), berpulang pada perspektifnya masing-masing. ${ }^{18}$ Lebih lanjut, Mahfud MD menawarkan hubungan hukum dengan politik pada tiga macam pola hubungan, yaitu

“... pertama hukum determinan politik dalam arti bahwa kegiatan-kegiatan politik diatur oleh dan harus tunduk pada aturanaturan hukum. Kedua, politik determinan atas hukum karena hukum merupakan hasil atau kristalisasi dari kehendak-kehendak politik yang saling berinteraksi dan (bahkan) saling bersaingan. Ketiga, politik dan hukum sebagai subsistem kemasyarakatan yang derajat determinasinya seimbang antara yang satu dengan yang lain, karena meskipun hukum merupakan produk keputusan politik tetapi begitu hukum ada maka semua kegiatan politik harus tunduk pada aturanaturan hukum.." ${ }^{19}$

Ada pula pola hubungan lain antara politik dan hukum yang disebut hubungan saling kebergantungan sebagaimana yang diungkapkan oleh Mochtar Kusumaatmadja bahwa "politik dan hukum itu interdepedensi, sebab politik tanpa hukum itu zalim sedangkan hukum tanpa politik itu lumpuh." 20

Dalam konteks hubungan politik dan hukum dalam sistem ketatanegaraan dengan pendekatan konsep trias politika maka kegiatan legislatif (pembuatan UU) lebih banyak membuat keputusan politik dibandingkan pekerjaan yang bersifat hukum. Lembaga legislatif lebih

\footnotetext{
17 Barry Friedman, "The Politics of Judicial Review," Texas Law Review, (Volume 84, No. 2, Desember 2005), hlm. 264.

18 Moh. Mahfud MD, Politik Hukum di Indonesia, cet.4 (Jakarta: Rajawali Pers, 2011) hlm. 16.

19 Ibid.

20 Sebagaimana dikutip oleh Mahfud MD, dalam Ibid, hlm. 5.
} 
dekat dengan politik daripada dengan hukum itu sendiri. ${ }^{21}$ Akan tetapi, memisahkan fungsi legislatif dengan memberikan kepada satu organ saja yang berwenang untuk membuat legislasi adalah sama tidak mungkinnya. Pandangan ideal yang mendasarkan pada prinsip pemisahan kekuasaan (separation of power) senantiasa merujuk pada pola sistem ketatanegaraan Amerika Serikat. Perumusan prinsip pemisahan kekuasaan ini adalah sebagaimana yang diungkapkan oleh Mahkamah Agung Amerika Serikat

"The Constitution divides the power of the government which it establishes into the three departments -- the executive, the legislative, and the judicial -- and unlimited power is conferred on no department or officer of the government. It is essential to the successful working of the system that the lines which separate those departments shall be clearly defined and closely followed, and that neither of them shall be permitted to encroach upon the powers exclusively confided to the others." 22

Dalam pandangan Kelsen, prinsip pemisahan kekuasaan tidaklah dapat diterapkan dalam praktek. Kelsen berpendapat bahwa fungsi negara adalah dalam hal pembentukan dan pelaksanaan hukum. Kedua fungsi ini disusun secara berjenjang sehingga tidak mungkin menentukan batas-batas antara kedua fungsi ini karena perbedaan antara pembentukan dan penerapan hukum bersifat relatif. ${ }^{23}$ Kelsen melanjutkan bahwa hampir tidak mungkin untuk melimpahkan pembuatan undangundang kepada "satu lembaga tersendiri" dan mengecualikan organ-organ Jainnya. Tidak pernah ada dalam praktek dimana fungsi legislasi dilakukan secara eksklusif oleh satu lembaga yang disebut legislatif. ${ }^{24}$ Kelsen melandaskan argumennya dengan menyatakan bahwa yang sebenarnya terjadi adalah distribusi kekuasaan dan bukanlah pemisahan kekuasaan. Ketika konstitusi suatu negara menyatakan dengan tegas mengadopsi prinsip pemisahan kekuasaan, pada kenyataannya fungsi legislatif tetap didistribusikan diantara beberapa organ, tetapi hanya satu organ saja yang diberi nama lembaga "legislatif". ${ }^{25}$

Bagi Kelsen, pengadilan yang menjalankan kewenangan untuk menguji Undang-Undang merupakan bentuk nyata dari penyimpangan atas prinsip pemisahan kekuasaan. ${ }^{26}$ Ketika pengadilan menguji UU maka pada dasarnya pengadilan melakukan fungsi legislasi. Pada saat yang sama pengadilan terlibat dalam politik legislasi.

"...all courts are part of politics to the extent that they make authoritative, policy relevant choices. Constitutional courts - by the very nature of the norms they are required to interpret and enforce - are highly visible in, and unusually generative of, legislative politics." 27

21 Satjipto Rahardjo, Beberapa Pemikiran tentang Ancangan antar Disiplin dalam Pembinaan Hukum Nasional, (Bandung: Sinar Baru, 1985) hlm. 79, sebagaimana dikutip dalam Moh. Mahfud MD, Politik Hukum di Indonesia, (Jakarta: Rajawali Pers, cet.4 , 2011) hlm. 16.

22 Kilbourn v. Thompson, 103 US 168 (1880), hlm. 169.

23 Hans Kelsen, Teori umum Hukum dan Negara, (Jakarta: Bee Media, 2007, cet. 1), hlm. 330.

24 Ibid.

25 Ibid., hlm. 333.

26 Ibid, hlm. 329.

27 Alec Stone Sweet "The Politics of Constitutional Review in France and Europe," International Journal of Constitutional Law, (Volume 5, Issue 1, January 2007. pp. 69-92),hlm. 72. 
Kelsen membedakan fungsi legislasi yang dilakukan oleh parlemen dan pengadilan. Parlemen merupakan positive legislators, sebab parlemen memiliki kewenangan konstitusional untuk membuat hukum berdasarkan dasar pijakan kebijakannya sendiri. Sedangkan peradilan yang memiliki kewenangan untuk menguji UU adalah negative legislators sebab peradilan tersebut menjalankan fungsi legislatif dalam rangka membatalkan UU. Suatu tindakan yang oleh Kelsen dianggap sebagai pembuatan UU secara negatif. ${ }^{28}$

Meskipun demikian, Kelsen sejak awal telah memberikan peringatan bahwa pembedaan fungsi legislasi parlemen dengan peradilan sebagai positive legislators dan negative legislators akan menjadi pudar ketika peradilan masuk dalam wilayah untuk melindungi hak konstitusional warga negara. Peradilan ketika memeriksa perkara dalam rangka melindungi hak konstitusional akan mendalami dan mencari ukuran ruang lingkup dari hak-hak konstitusional. Dalam konteks ini, peradilan akan menjadi omnipotent superlegislators. ${ }^{29}$ Prediksi Kelsen ini menjadi kenyataan. Dalam prakteknya, mahkamah konstitusi diberbagai negara yang bertugas melindungi hak konstitusional warga negara berubah menjadi positive legislators.

\section{Konsep Judicialisation of Politics}

Dengan dibekali kewenangan untuk menguji UU, peradilan terlibat dalam pengubahan kebijakan yang selama ini menjadi urusan parlemen dan pemerintah. Pengadilan terlibat dalam penyelesaian persoalan perlindungan hak konstitusional warga negara mengenai kebebasan berserikat, kebebasan warga negara dalam menyatakan pendapat dan berekspresi, hak dan kedudukan warga negara yang sama dalam hukum dan pemerintahan, kebebasan memeluk agama dan kepercayaan, hingga penyelesaian perkara mengenai kebijakan publik yang menyangkut prosedur dalam hukum acara pidana, perdagangan, sistem pendidikan, ketenagakerjaan, kehutanan sampai dengan persoalan kebijakan mengenai lingkungan hidup. Karenanya Ran Hirschl mendefinisikan yudisialisasi politik sebagai“... the ever-accelerating reliance on courts and judicial means for addressing core moral predicaments, public policy questions, and political controversies." 30

Yudisialisasi politik telah menjadi suatu konsep ilmiah yang meyakinkan, dimana banyak ditemukan artikel ilmiah yang mengulas mengenai peran lembaga peradilan dalm kajian teoritik. ${ }^{31}$ Begitu pula kajian-kajian ilmiah dengan melalui pendekatan komparatif

$28 \quad$ Op. Cit., Kelsen, hlm. 327-328.

29 Hans Kelsen, The Jurisdictional Protection of the Constitution, sebagaimana dikutip dalam Alec Stone Sweet, Op. Cit. hlm. 84.

30 Ran Hirschl, "The New Constitution and the Judicialization of Pure Politics Worldwide”, Fordham Law Review, (Vol. 75, Issue 2, 2006), hlm. 721-754.

31 Lihat C. Neal Tate \& Torbjorn Vallinder (eds.), The Global Expansion of Judicial Power,( New York, London: New York University Press, 1995) ; Martin Shapiro \& Alec Stone Sweet, On Law, Politics, and Judicialization, (Oxford, 2002 ); John Ferejohn, "Judicializing Politics, Politicizing Law", 65 Law \& Contemporary Problems, (Volume 65 Issue 41,2002); Ran Hirschl, "Resituating the Judicialization of Politics: Bush v. Gore as a Global Trend", Canadian Journal of Law and Jurisprudence, ( Volume. 15, Issue 2, 2002), hal 191; Richard H. Pildes, "The Supreme Court, 2003 Term: Foreword: The Constitutionalization of Democratic Politics”, Harvard Law Review , (Volume. 118, Issue $29,2004)$. 
misalnya, kajian yudisialisasi politik di kawasan Amerika Latin,, ${ }^{32}$ di kawasan $\mathrm{Asia}^{33}$ dan di kawasan Asia Tenggara terutama menyoroti Filipina. ${ }^{34}$ Banyak juga kajian yudisialisasi politik yang terjadi di sebuah negara seperti di Brazil, ${ }^{35}$ Mesir, ${ }^{36}$ Jerman, ${ }^{37}$ Israel, ${ }^{38}$ Belanda, ${ }^{39}$ Korea Selatan, ${ }^{40}$ dan Indonesia. ${ }^{41}$

\section{Terlibatnya Mahkamah Konstitusi Dalam Fungsi Legislasi}

MK yang dibentuk pada Agustus 2003 hingga saat ini telah memeriksa ratusan perkara pengujian UU. Keterlibatan MK dalam proses legislasi mengalami peningkatan dari tahun ke tahun. Tren peningkatan jumlah penerimaan permohonan perkara pengujian UndangUndang terhadap UUD 1945 bisa dilihat dari grafik 1. Bila diperhatikan, terdapat penurunan penerimaan perkara pengujian UU diujung grafik tersebut. Namun demikian, data yang disajikan adalah hingga Agustus 2015 sehingga besar kemungkinan jumlah penerimaan perkara pengujian UU akan meningkat pada akhir tahun 2015.

Grafik 1. Tren Penerimaan Permohonan Perkara Pengujian UU dari 2003 s.d. Agustus 2015

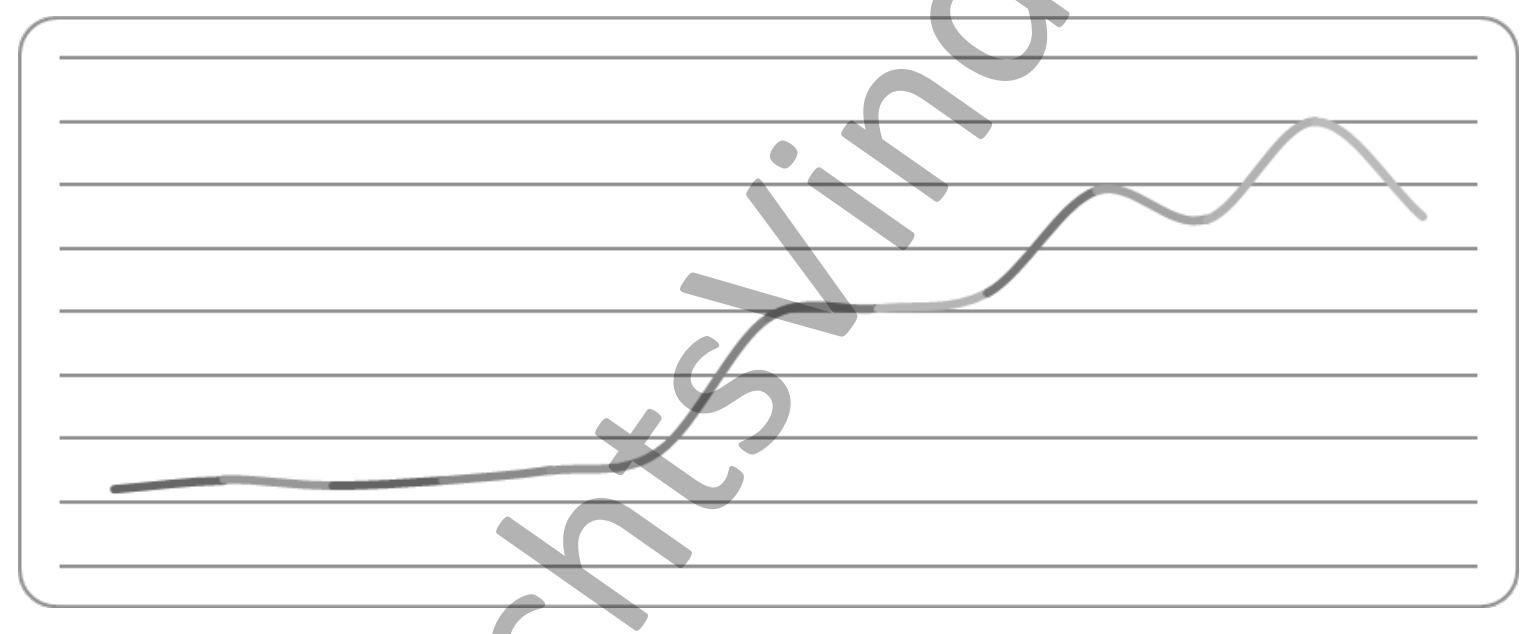

Sumber: diolah dari data Kepaniteraan dan Sekretariat Jenderal Mahkamah Konstitusi

\footnotetext{
Rachel Sieder (eds.), The Judicialization of Politics in Latin America, (New York: Palgrave Macmillan, 2005).

Bjoern Dressel (ed.), The Judisialization of Politics in Asia,( Routledge Law in Asia, 2012),

34 C. Neal Tate, "The Judicialization of Politics in the Philippines and Southeast Asia," International Political Science Review, (Volume15, no. 2, April 1994), hlm. 187-197.

35 Estefânia Maria De Queiroz Barboza dan Katya Kozicki, "Judicialization of Politics and the Judicial Review of Public Policies by the Brazilian Supreme Court", Revista Direito GV, (Volume 8, no. 1, 2012 ), hlm. 59-85.

36 Tamir Moustafa, "Law versus the State: The Judicialization of Politics in Egypt”, Law \& Social Inquiry, (Volume 28, Issue 4, 2003), hlm. 883-930.

37 Christine Landfried. "The Judicialization of Politics in Germany," International Political Science Review,( Volume 15, Issue 2, 1994), hlm. 113-124.

38 Martin Edelman, "The Judicialization of Politics in Israel." International Political Science Review, (Volume 15, Issue 2, 1994), hlm. 177-186.

39 Jan Ten Kate, dan Peter J. Van Koppen, "Judicialization of Politics in the Netherlands: Towards a Form of Judicial Review." International Political Science Review, (Volume 15, Issue 2, 1994), hlm. 143-151.

40. Jonghyun Park, "The Judicialization of Politics in Korea," Asian-Pacific Law \& Policy Journal, (Volume 10, Number 1, 2008), hlm. 62.

41 Bisariyadi, Yudisialisasi Politik dan Sikap Menahan-diri: Peran Mahkamah Konstitusi dalam menguji UndangUndang,( Jurnal Konstitusi, Volume 12, No. 3, 2015).
} 
Hal ini menunjukkan tren positif atas antusiasme warga negara untuk terlibat dalam proses bernegara dengan mengajukan judicial review produk legislasi ke MK. Sebagai sebuah lembaga peradilan, MK terikat dengan asas-asas yang diadopsi dari Hukum Acara Perdata bahwa hakim bersifat menunggu. Artinya, MK tidak dapat mengambil inisiatif untuk memeriksa suatu UU yang disinyalir melanggar konstitusi. MK harus menunggu warga negara atau pihak lain yang masuk dalam kompetensi sebagai pemohon $^{42}$ untuk mengajukan permohonan mengenai adanya pelanggaran konstitusional dari suatu norma dalam UU.

Disisilain, MKketikamengadiliperkarajudicial review terlibat dalam sebuah proses legislasi. Oleh karenanya, dalam memeriksa perkara MK senantiasa menghadirkan pemerintah dan parlemen sebagai pembentuk UU dalam persidangan. Pemerintah dan DPR hadir dalam persidangan untuk memeberikan keterangan mengenai latar belakang pengambilan suatu kebijakan yang kemudian dituangkan dalam UU.

Putusan-putusan yang dikeluarkan oleh MK jelas memiliki dampak yang signifikan terhadap kehidupan politik berbangsa dan bernegara. Ilustrasi rekapitulasi putusan yang pernah dikeluarkan MK (tabel 1.) tidak dapat memperlihatkan besar kecilnya dampak putusan MK di masyarakat. Namun, data tersebut paling tidak memberikan gambaran sekilas mengenai variasi dan dinamika putusan judicial review atas produk legislasi. Variasi antara putusan yang menolak dan mengabullkan permohonan demikian beragam dari tahun ke tahun sehingga tidak terlihat adanya tren yang konsisten.

Tabel 1. Rekapitulasi Putusan Pengujian UU terhadap UUD 1945 tahun 2003 s.d. Agustus 2015

\begin{tabular}{|c|c|c|c|c|c|c|c|c|}
\hline \multirow[b]{2}{*}{ No } & \multirow[b]{2}{*}{ Tahun } & \multirow{2}{*}{$\begin{array}{l}\text { Jumlah } \\
\text { Putusan }\end{array}$} & \multicolumn{4}{|c|}{ Putusan } & \multicolumn{2}{|c|}{ Ketetapan } \\
\hline & & & Kabul & Tolak & $\begin{array}{c}\text { Tidak } \\
\text { Diterima }\end{array}$ & Gugur & $\begin{array}{c}\text { Tarik } \\
\text { Kembali }\end{array}$ & $\begin{array}{c}\text { Tidak } \\
\text { Berwenang }\end{array}$ \\
\hline 1 & 2003 & 4 & 0 & 0 & 1 & 0 & 3 & 0 \\
\hline 2 & 2004 & 35 & 11 & 9 & 11 & 0 & 4 & 0 \\
\hline 3 & 2005 & 28 & 10 & 14 & 4 & 0 & 0 & 0 \\
\hline 4 & 2006 & 29 & 8 & 8 & 11 & 0 & 2 & 0 \\
\hline 5 & 2007 & 27 & 4 & 11 & 7 & 0 & 5 & 0 \\
\hline 6 & 2008 & 34 & 10 & 12 & 7 & 0 & 5 & 0 \\
\hline 7 & 2009 & 51 & 15 & 18 & 11 & 0 & 7 & 0 \\
\hline 8 & 2010 & 61 & 18 & 22 & 16 & 0 & 5 & 0 \\
\hline 9 & 2011 & 94 & 21 & 29 & 35 & 0 & 9 & 0 \\
\hline 10 & 2012 & 97 & 30 & 31 & 30 & 0 & 6 & 0 \\
\hline 11 & 2013 & 110 & 22 & 52 & 22 & 1 & 12 & 1 \\
\hline 12 & 2014 & 131 & 29 & 41 & 37 & 6 & 17 & 1 \\
\hline 13 & 2015 & 90 & 12 & 27 & 39 & 2 & 9 & 1 \\
\hline & umlah & 791 & 190 & 274 & 231 & 9 & 84 & 3 \\
\hline
\end{tabular}

Sumber: Data Kepaniteraan dan Sekretariat Jenderal Mahkamah Konstitusi

42 Pasal 51 ayat (1) UU nomor 8 tahun 2011 tentang Perubahan atas UU nomor 24 tahun 2003 tentang Mahkamah Konstitusi. 
Gambaran utuh mengenai dampak putusan MK, justru akan terlihat jelas bilamana dikaji dari tiap-tiap putusan yang pernah dikeluarkan MK. Secara umum, dampak putusan MK dapat lihat dalam dua kategori yaitu, dampak langsung dan dampak tidak langsung. Yang dimaksud dengan dampak langsung adalah konsekuensi yang timbul secara serta-merta setelah putusan MK dikeluarkan. Jenis dampak putusan ini terlihat dengan jelas ketika MK bertindak sebagai negative legislators dengan membatalkan keberlakuan materi muatan dalam ayat, pasal dan/atau bagian UU, bahkan membatalkan keberlakuan seluruh UU. Hingga kini, terdapat 6 (enam) UU yang dibatalkan keberlakuannya atas putusan MK, yaitu: UU Komisi Kebenaran dan Rekonsiliasi (UU Nomor 27 Tahun 2004), ${ }^{43}$ UU Ketenagalistrikan (UU Nomor 20 Tahun 2002), ${ }^{44}$ UU Badan Hukum Pendidikan (UU Nomor 9 Tahun 2009), ,5 UU Perkoperasian (UU Nomor 17 Tahun 2012), ${ }^{46}$ UU Sumber Daya Air (UU Nomor 7 Tahun 2004), ${ }^{47}$ dan UU Perubahan Kedua dari UU MK (UU Nomor 4 tahun 2014). ${ }^{48}$

Disisi lain, putusan MK pun memiliki dampak tidak langsung. Yang dimaksud dengan imbas putusan $\mathrm{M}$ yang tidak langsung adalah bahwa putusan tidak serta merta dapat berlaku. Terdapat tahapan dan proses tindak lanjut dari putusan MK tersebut. Variasi putusan MK yang memiliki dampak tidak langsung ini sangat beragam. Sebuah penelitian pernah memetakan variasi keberagaman putusan MK ini. ${ }^{49}$ Dalam penelitian tersebut, putusan MK dikategorisasikan pada 5 model, yaitu (1) model putusan yang secara hukum membatalkan dan menyatakan tidak berlaku (Legally Null and Void); (2) model putusan konstitusional bersyarat (conditionally constititional); (3) model putusan inkonstitusional bersyarat (conditionally unconstititional); (4) model putusan yang menunda pemberlakuan putusannya (limited constitutional) dan (5) model putusan yang merumuskan norma baru. Jenis model putusan dalam kategori (2) sampai dengan (5) merupakan kelompok putusan yang tidak berdampak langsung.

Dalam pendekatan komparatif, penelitian yang sama pernah dilakukan oleh Christian Behrendt. ${ }^{50}$ Penelitiannya berkutat pada modelmodel putusan yang dikembangkan oleh Mahkamah Konstitusi di Belgia, Perancis dan Jerman dimana putusan peradilan mengandung perintah kepada parlemen untuk menyusun ketentuan legislasi sesuai dan berdasarkan putusandimaksud. Model putusan inidisebutnya dengan istilah injunctions. Dalam kesimpulan akhir, Behrendt secara tegas menyampaikan bahwa tiada pilihan lain kecuali mengabaikan teori negative legislator. Kesimpulan ini mengarahkan bahwa peran pengadilan yang 
telah sedemikian besar dalam proses legislasi menandaskan kedudukan pengadilan yang juga menjadi positive legislator.

\section{Putusan MK dalam Perkara Politik Legislasi}

Bilamana mencermati putusan-putusan MK dapat ditarik kesimpulan bahwa keterlibatan MK dalam politik legislasi tidak hanya dalam hal perkara-perkara politik legislasi sehari-hari yang bersifat sederhana. Beberapa perkara yang ditangani oleh MK masuk dalam ranah politik yang luar biasa karena kebijakan yang diadili oleh MK menentukan arah perjalanan bangsa Indonesia dan melibatkan nasib kebanyakan warga negara. Ran Hirschl menyebutnya dengan istilah "mega-politics". ${ }^{51}$ Yang dimaksud dengan kasus mega-politics menurut Hirschl adalah “... core political controversies that define the boundaries of the collective or cut through the heart of entire nations." ${ }^{52}$ Kategorisasi kasuskasus yang termasuk dalam mega politics adalah (1) perkara berkaitan dengan proses dan hasil pemilu; (2) Kewenangan inti dari pemerintahan; (3) Perkara memberi legitimasi atas perubahan rezim kekuasaan; (4) Perkara yang berkenaan dengan keadilan transisional; dan (5) Pendefinisian jati diri bangsa. Berikut ini akan diuraikan perkara-perkara politik legislasi yang pernah diputus oleh MK berdasarkan kategorisasi kasus mega politics yang dirumuskan oleh Ran Hirschl.

\section{a. Perkara Berkaitan dengan Proses dan Hasil Pemilu}

Lingkup wilayah kewenangan MK yang memiliki nuansa politik yang paling kentaladalah ketika MK sebagai sebuah lembaga peradilan terlibat dalam perkara yang menentukan proses demokratisasi sebuah bangsa. Tidak hanya dalam menilai proses yang berlangsung tetapi MK juga terllibat dalam menentukan hasil dari pemilu itu. Dalam menangani perkara yang berkaitan dengan proses dan hasil pemilu ada dua kewenangan konstitusional yang diperankan oleh MK, yaitu dalam hal pengujian UU terhadap UUD dan kewenangan untuk menyelesaikan perselisihan hasil pemilu.

Dalam hal proses pemilu, perkara pengujian UU terhadap UUD yang berkaitan dengan norma aturan penyelenggaraan pemilu menjadi perhatian utama para pemohon terutama disaat-saat menjelang pemilu. Aturan mengenai syarat pencalonan, hal-hal yang memungkinkan partai politik menjadi peserta pemilu, mekanisme pemungutan suara, hingga tata cara penghitungan suara pernah diputus oleh MK. Syarat pencalonan seseorang untuk ikut dalam pemilu menjadi perkara yang banyak diperiksa dan diadili oleh MK. Persoalan syarat yang dinilai diskriminatif menjadi alasan yang mengemuka dalam judicial review kasus syarat pencalonan. Diantaranya persyaratan yang melarang bekas anggota Partai Komunis Indonesia sebagai anggota parlemen, ${ }^{53}$ syarat yang mengharuskan seorang calon anggota Dewan Perwakilan

\footnotetext{
51 Ran Hirschl, "The Judicialization of Mega-Politics and the Rise of Political Courts". Annual Review of Political Science, Vol. 11, 2008. diunduh SSRN: http://ssrn.com/abstract=1138008.

52 Ibid., hlm. 5

53 Putusan Nomor 011-017/PUU-I/2003 bertanggal 24 Februari 2004 tentang Pengujian Pasal 60 huruf g UndangUndang Nomor 12 Tahun 2003 tentang Pemilihan Umum Anggota Dewan Perwakilan Rakyat, Dewan Perwakilan Daerah, dan Dewan Perwakilan Rakyat Daerah.
} 
Daerah untuk dapat mengikuti pemilu dari domisilinya di provinsi yang akan diwakili, ${ }^{54}$ kemudian syarat yang melarang mantan narapidana mengikuti pemilu. ${ }^{55}$

Tidak hanya dalam persoalan syarat pencalonan seseorang untuk ikut dalam pemilu, MK juga terlibat dalam merumuskan persoalan mekanisme pemungutan suara. Putusan perkara mengenai perumusan mekanisme pemungutan suara bagi warga negara yang tidak terdaftar dalam Daftar Pemilih Tetap (DPT) merupakan suatu hal yang monumental. ${ }^{56}$ Pemilu legislatif tahun 2009 memiliki persoalan dalam hal warga negara yang tidak tercantum dalam DPT tidak dapat memberikan suaranya dalam biliki-bilik suara. Persoalan ini perlu segera diselesaikan dalam penyelenggaraan pemilu Presiden/Wakil Presiden tahun 2009 yang hanya berjarak 4 bulan. ${ }^{57}$ Yang lebih monumental adalah MK memutus perkara ini pada tanggal 6 Juli 2009,3 hari sebelum penyelenggaran pemilu Presiden dan Wakil Presiden. Mengingat tenggang waktu yang sedemikian sempit serta persoalan yang terkandung dalam perkara ini merupakan perkara yang besar melibatkan jaminan perlindungan atas hak memilih warga negara dalam pemilu maka MK bertindak sebagai positive legislators.

Dalam putusannya, MK mengabaikan aturan legislasi yang menentukan bahwa pemilih wajib terdaftar dalam DPT. Sebaliknya, MK membuka lebar hak memilih warga negara sebagai pemilih meskipun tidak terdaftar dalam DPT dengan mempersyaratkan (1) menunjukkan Kartu Tanda Penduduk (KTP) atau paspor yang masih berlaku; (2) dilengkapi dengan Kartu Keluarga (KK) atau sejenisnya; (3) hanya berlaku di Tempat Pemungutuan Suara yang berada dalam lingkungan sesuai dengan KTP; (4) harus mendaftarkan diri terlebih dulu; dan (5) hanya dapat dilakukan satu jam sebelum selesainya waktu pemungutan suara.

Selain itu, MK juga terlibat dalam politik legislasi dalam tata cara penghitungan suara. ${ }^{58}$ Ketika itu aturan penghitungan suara pemilu legislatif 2009 memunculkan beragam tafsir. ${ }^{59}$

54 Putusan Nomor 10/PUU-VI/2008 bertanggal 1 Juli 2008 tentang pengujian Pasal 12 huruf c Undang-Undang Nomor 10 Tahun 2008 tentang Pemilihan Umum Anggota Dewan Perwakilan Rakyat, Dewan Perwakilan Daerah, dan Dewan Perwakilan Rakyat Daerah (UU Pemilu DPR, DPD, dan DPRD).

55 Putusan Nomor 4/PUU-VH/2009 bertanggal 24 Maret 2009 tentang pengujian Pasal 12 hurufg dan Pasal 50 ayat (1) huruf g UU Pemilu DPR, DPD, dan DPRD dan Pasal 58 huruf f UU Pemda.

Kemudian MK mempertimbangkan kembali dalam Putusan Nomor 42/PUU-XIII/2015 bertanggal 9 Juli 2015 dimana MK berpendapat bahwa syarat tersebut tidak lagi diperlukan dengan alasan bahwa seorang mantan narapidana yang telah secara berani dan terbuka mengemukakan statusnya tersebut tidak sepatutnya diperikan hukuman tambahan dengan menunggu jeda hingga 5 tahun. Oleh karenanya, syarat batas jangka waktu 5 tahun sejak selesai menjalani hukuman tidak lagi berlaku.

56 Putusan Nomor 102/PUU-VII/2009 bertanggal 6 Juli 2009.

57 Pemilu legislatif tahun 2009 diselenggarakan pada tanggal 9 April 2009 dan pemilu Presiden/Wakil Presiden dilaksanakan pada tanggal 9 Juli 2009.

58 Putusan Nomor 110-111-112-113/PUU-VII/2009, bertanggal 7 Agustus 2009.

59 Paragraf [3.26] Putusan Nomor 110-111-112-113/PUU-VII/2009 menyatakan frasa "suara" dalam Pasal 205 ayat (4) UU 10/2008 menimbulkan multitafsir yang dapat dikelompokkan menjadi tiga penafsiran: Pertama, yang dimaksud dengan suara adalah termasuk suara yang diperoleh partai politik yang telah diperhitungkan pada tahap pertama secara keseluruhan; Kedua, suara yang dimaksud dalam frasa tersebut adalah sebagai sisa suara dari seluruh suara yang diperoleh partai politik setelah dikurangi dengan BPP atau kelipatannya yang telah dikonversi menjadi kursi; Ketiga, suara dari partai yang tidak mencapai BPP tetapi perolehan suaranya sama atau melebihi 50\% BPP sebagai dasar penghitungan tahap kedua; 
Atas dasar pertimbangan tersebut, MK merumuskan tata cara penghitungan suara yang seharusnya dilakukan oleh penyelenggara pemilu.

Adanya kewenangan MK untuk menyelesaikan perselisihan hasil pemilu juga menjadikan MK terlibat dalam politik. Setidaknya, pelaksanaan kewenangan ini masuk dalam kategorisasi mega-politics menurut Ran Hirschl. Setiap 5 tahun sekali, MK kebanjiran perkara pemilu legislatif. Akan tetapi, pembahasan mengenai kewenangan MK untuk menyelesaikan perkara pemilu berada diluar dari konteks keterlibatan MK dalam politik legislasi karena obyek perkara yang diperiksa oleh MK bukanlah produk legislasi melainkan keputusan penyelenggara pemilu, dalam hal ini Komisi Pemilihan Umum (KPU).

\section{b. Kewenangan Inti dari Pemerintahan}

Perkara politik yang tergolong besar adalah ketika lembaga peradilan terlibat dalam penentuan kebijakan yang biasanya hanya menyangkut pada kewenangan eksekutif semata seperti keamanan nasional, politik luar negeri dan kebijakan fiskal. ${ }^{60}$ Dalam konteks ini, salah satu contoh kasus yang dapat diuraikan adalah ketika MK terlibat dalam politik legislasi penyusunan anggaran yang tertuang dalam
APBN untuk memutus konstitusionalitas anggaran pendidikan sebesar $20 \% .{ }^{61} \mathrm{MK}$ empat kali menguji perkara konstitusionalitas anggaran pendidikan dalam APBN antara periode 20052008. ${ }^{62}$ Dalam pengujian perkara ini, MK seolah mengingatkan perlunya proses perubahan anggaran secara bertahap. Pada putusan pertama pengujian anggaran pendidikan dalam APBN, MK menyatakan bahwa UU APBN bertentangan dengan UUD karena tidak memenuhi alokasi anggaran pendidikan yang ditentukan konstitusi. Namun demikian, MK mempertimbangkan bahwa pembatalan UU APBN tidak mungkin diterapkan, dengan alasan " ... akan menimbulkan kekacauan (governmental disaster) dalam administrasi keuangan negara, yang dapatmengakibatkan ketidakpastian hukum (rechtsonzekerheid) dan bahkan akibatnya dapat akan lebih buruk apabila ternyata anggaran pendidikan pada APBN sebelumnya lebih kecil jumlahnya."63

Oleh karenanya, UU APBN tahun 2005 tetap dinyatakan berlaku. Pada putusan kedua dan ketiga, MK mengambil langkah yang berbeda. MK menyatakan bahwa dengan adanya putusan 012/PUU-III/2005, pembentuk UU sudah seharusnya mengetahui dengan persis bahwa anggaran pendidikan yang kurang dari 20\% bertentangan UUD 1945. Akan tetapi pada kenyataannya pembentuk UU tetap tidak

60 Op. Cit. h. 9.

61 Pasal 31 ayat (4) UUD 1945

62 Keempat putusan MK mengenai pengujian UU APBN yang menyangkut anggaran pendidikan adalah:

(i) Putusan Nomor 012/PUU-III/2005 bertanggal 19 Oktober 2005 perihal Pengujian Undang-Undang Nomor 36 Tahun 2004 tentang Anggaran Pendapatan dan Belanja Negara Tahun Anggaran 2005;

(ii) Putusan Nomor 026/PUU-III/2005 bertanggal 22 Maret 2006 perihal Pengujian Undang-Undang Nomor 13 Tahun 2005 tentang Anggaran Pendapatan dan Belanja Negara Tahun Anggaran 2006;

(iii)Putusan Nomor 026/PUU-IV/2006 perihal Pengujian Undang-Undang Nomor 18 Tahun 2006 tentang Anggaran Pendapatan dan Belanja Negara Tahun Anggaran 2007.

(iv) Putusan Nomor 13/PUU-VI/2008 bertanggal 13 Agustus 2008 tentang Pengujian Undang-Undang Nomor 16 Tahun 2008 tentang Perubahan Atas Undang-Undang Nomor 45 Tahun 2007 tentang Anggaran Pendapatan dan Belanja Negara Tahun Anggaran 2008 (UU APBN 2008)

63 Putusan Nomor 012/PUU-III/2005, h. 62 
memenuhi ketentuan batas terendah anggaran pendidikan dalam UU APBN tahun 2006 dan UU APBN tahun 2007. Oleh karenanya, MK membatalkan aturan yang memberi akibat hukum atas inkonstitusionalitas anggaran pendidikan secara terbatas, yaitu tentang batas tertinggi dan bukan terhadap keseluruhan UU APBN demi menghindari kemacetan dan kekacauan dalam penyelenggaraan pemerintahan. ${ }^{64}$ Oleh karena itu, pada putusan kedua MK membatalkan aturan "sepanjang menyangkut anggaran pendidikan sebesar 9,1\% (sembilan koma satu persen) sebagai batas tertinggi." ${ }^{65}$ Pada putusan ketiga, MK membatalkan aturan "sepanjang menyangkut anggaran pendidikan sebesar $11,8 \%$ (sebelas koma delapan persen) sebagai batas tertinggi."66 Setelah putusan-putusan ini terdapat salah satu putusan yang menyangkut anggaran pendidikan sehingga penting untuk dikutip yaitu putusan nomor 24/PUU-V/2007 dimana MK menetapkan gaji pendidik sebagai bagian dari komponen pendidikan dimasukkan dalam penyusunan APBN dan APBD. ${ }^{67}$ Pertimbangan memasukkan komponen gaji pendidik akan memudahkan pembuat UU untuk memenuhi kewajiban menetapkan anggaran pendidikan sekuruangkurangnya $20 \%$ dalam APBN. ${ }^{68}$ Pada putusan MK yang keempat mengenai pengujian anggaran pendidikan dalam APBN, ${ }^{69} \mathrm{MK}$ mengambil langkah yang lebih tegas. MK menilai adanya kesengajaan pembentuk UU melanggar UUD
$1945 .^{70}$ Oleh karenanya, UU APBN Perubahan tahun 2008 harus dinyatakan inkonstitusional secara keseluruhan karena tidak memenuhi anggaran pendidikan sekurang-kurangnya $20 \%$. Akan tetapi, dengan mempertimbangkan faktor potensi resiko kekacauan administrasi keuangan negara putusan MK tidak secara serta merta dinyatakan berlaku sejak diucapkan melainkan dinyatakan berlaku hingga dibuatnya UU APBN baru untuk tahun anggaran 2009. Pernyataan tegas MK dalam kalimat terakhir putusan menyatakan bahwa

"Untuk mendorong agar semua daerah (provinsi, kabupaten/ kota) memprioritaskan anggaran pendidikan sekurang-kurangnya 20\% dalam APBD-nya, dan mencegah pengurangan terhadap makna Indonesia sebagai negara hukum, serta menghindari terjadinya delegitimasi terhadap konstitusi sebagai hukum tertinggi, maka Mahkamah perlu sekali lagi mengingatkan pembentuk undang-undang untuk selambat-lambatnya dalam UU APBN Tahun Anggaran 2009 harus telah memenuhi kewajiban konstitusionalnya menyediakan anggaran sekurang-kurangnya $20 \%$ untuk pendidikan." ${ }^{\prime 1}$

\section{c. MK Memberi Legitimasi Perubahan Rezim Kekuasaan}

Contoh kasus yang mudah dirujuk menyangkut keterlibatan MK dalam penentuan legitimasi atas perubahan rezim kekuasaan adalah ketika MK memeriksa dan memutus perkara perselisihan hasil pemilihan Presiden dan Wakil Presiden. Dalam setiap pemilu 
Presiden dan Wakil Presiden, MK senantiasa memeriksa dan mengadili perkara perselisihan hasil pemilu ini. Pada pemilu Presiden dan Wakil Presiden tahun 2004, MK menerima perkara perselisihan hasil pemilu yang diajukan oleh pasangan Wiranto - Salahuddin Wahid. ${ }^{72}$ Kemudian, pada pemilu Presiden dan Wakil Presiden tahun 2009, MK mengadili perkara pemilu yang diajukan oleh pasangan Jusuf Kalla - Wiranto, sebagai Pemohon I, dan pasangan Megawati Soekarnoputri - Prabowo Subianto, sebagai Pemohon II, dimana dalam putusannya MK menggabungkan kedua perkara ini. ${ }^{73}$ Paling mutakhir adalah perselisihan hasil pemilu 2014 dimana pasangan Prabowo Subianto - Hatta Rajasa menggugat pasangan Joko Widodo Jusuf Kalla. ${ }^{74}$

Bila ditarik pada tingkat daerah, MK juga berpengaruh dalam menentukan perubahan rezim kekuasaan daerah ketika mengadili perkara perselisihan hasil pemilihan kepala daerah antara tahun 2008-2014. Catatan Kepaniteraan Mahkamah Konstitusi menunjukkan bahwa dalam kurun waktu itu, MK telah memutus 698 perkara. Jumlah ini tidak identik dengan jumlah daerah yang mengajukan perkara perselisihan hasil pemilihan kepala daerah namun setidaknya data ini menunjukkan banyaknya rezim kekuasaan daerah yang ditentukan melalui meja majelis hakim konstitusi.

Namun demikian, contoh perkara diatas adalah pelaksanaan kewenangan MK dalam konteks yang berbeda dengan politik legislasi.
Putusan yang menjadi landmark, dalam hal politik legislasi untuk menentukan perubahan sebuah rezim pemerintahan adalah ketika MK diminta untuk menafsirkan Pasal 6A UUD 1945. ${ }^{75}$ Pada pemilu Presiden dan Wakil Presiden tahun 2014 hanya memunculkan 2 pasangan calon yang akan mengikuti pemilu. Padahal, Konstitusi tidak mengatur kondisi pemilu dimana hanya terdapat 2 pasangan calon. Hal ini diamini oleh MK, ketika menelusuri original intent penyusunan Pasal 6A UUD 1945 melalui risalah rapat pembahasan perubahan UUD $1945 .{ }^{76}$ Penyusunan Pasal 6A UUD 1945 dikonstruksikan hanya untuk kondisi dimana terdapat pasangan calon peserta pemilu lebih dari 2 pasangan. Oleh karenanya, syarat utnuk menang dalam pemilu Presiden dan Wakil Presiden tidak hanya faktor suara terbanyak, tetapi juga faktor persebaran suara pemilih yang merata. MK berpendapat bahwa prinsip yang paling penting untuk ditegakkan adalah prinsip kedaulatan rakyat sehingga Presiden terpilih memiliki legitimasi yang kuat. Pada akhirnya, MK memutuskan bilamana hanya terdapat dua pasangan calon peserta pemilu Presiden dan Wakil Presiden maka tidak perlu dilakukan pemilihan putaran kedua. Prinsip representasi keterwakilan dan persebaran jumlah pemilih yang merata dari seluruh daerah di Indonesia telah dipenuhi ketika tahap pencalonan pasangan tersebut diajukan dan didukung oleh gabungan partai politik nasional. ${ }^{77}$

\footnotetext{
Putusan Nomor 062/PHPU.B-II/2004 tanggal 9 Agustus 2004.

Putusan Nomor 108-109/PHPU.B-VII/2009.

Putusan Nomor 1/PHPU.PRES-XII/2014.

Putusan Nomor 50/PUU-XII/2014 tanggal 3 Juli 2014.

Paragraf [3.20], Putusan Nomor 50/PUU-XII/2014 tanggal 3 Juli 2014.

7 Ibid.
} 


\section{d. Perkara yang Berkenaan dengan Keadilan Transisional}

Mengapa kategorisasi ini termasuk dalam mega-politic? Menurut Ran Hirschl, keberadaan MK yang dimaksudkan untuk melindungi hak konstitusional warga negara berupaya untuk memperbesar lingkup wilayah pengaruh dan peranannya tersebut. ${ }^{78}$ Terlebih, diberbagai belahan dunia pembentukan mahkamah konstitusi adalah seiring dengan adanya proses perubahan dari rezim yang otoritarian. Dalam rezim otoritarian, pelanggaran HAM kerap terjadi. Dengan demikian, kehadiran MK adalah untuk memulihkan kondisi hak-hak warga negara yang terkoyak dimasa lalu.

Hal demikian juga terjadi di Indonesia. Ada 3 putusan MK yang penting dalam mekanisme keadilan transisional. Dua putusan MK terkait dengan keberadaan pengadilan $\mathrm{HAM}^{79}$ sedangkan satu putusan adalah mengenai Komisi Kebenaran dan Rekonsilisasi. ${ }^{80}$

Pada putusan mengenai pengadilan HAM, keduanya diajukan oleh terpidana kasus pelanggaran HAM. Adalah Abilio Jose Osorio Soares ${ }^{81}$ dan Eurico Guterres ${ }^{82}$ yang menjadi pemohon pengujian $U U$ mengenai pengadilan HAM. Pengujian pertama mengenai keberadaan pengadilan HAM diajukan oleh Abilio Jose Soares. Pemohon mempertanyakan keberadaan pengadilan HAM yang menabrak asas non-retroaktif. Pada pertimbangannya, MK berpendapat bahwa “...mekanisme keadilan transisional (transitional justice), terlepas dari sedikit banyaknya, pasti mengandung elemen pengesampingan asas non-retroaktif." ${ }^{83}$ Dengan demikian, keberadaan pengadilan HAM adhoc adalah konstitusional meskipun mengesampingkan asas non-retroaktif. Akan tetapi, pembentukan pengadilan HAM harus memenuhi syarat yang sangat ketat, yaitu (i) hanya atas peristiwa tertentu yang locus delicti dan tempus delicti-nya dibatasi; (ii) peristiwa tersebut harus dinilai oleh DPR terlebih dahulu; dan (iii) dibentuk berdasarkan Keputusan Presiden atas usul DPR. ${ }^{84}$ Sedangkan, permohonan yang diajukan oleh Eurico Guterres adalah untuk menegaskan mekanisme penilaian yang diberikan oleh DPR tersebut. MK berpendapat dalam memberikan rekomendasi pembentukan pengadilan HAM ad hoc harus memperhatikan hasil penyelidikan dan penyidikan dari institusi yang berwenang, yaitu Komnas HAM sebagai penyelidik dan Kejaksaan Agung sebagai penyidik. ${ }^{85}$

Selain pembentukan pengadilan HAM ad hoc, upaya untuk menyelesaikan pelanggaran HAM di masa lalu juga dibentuk Komisi Kebenaran dan Rekonsilisasi (KKR) sebagai lembaga ekstra yudisial. ${ }^{86}$ Pembentukan KKR digugat keberadaannya oleh para pemohon

Op. Cit., Hirschl. h. 12.

(i) Putusan Nomor 065/PUU-II/2004, Tanggal 3 Maret 2005; dan

(ii) Putusan Nomor 18/PUU-V/2007, tanggal 21 Februari 2008.

80 Putusan Nomor 006/PUU-IV/2006, tanggal 7 Desember 2006.

81 Pemohon perkara 065/PUU-II/2004, terpidana pelanggaan HAM berat Timor Timur dipidana berdasarkan putusan kasasi MA No. 04K/PID.HAM/ AD.HOC/2003 tanggal 1 April 2004.

82 Pemohon perkara 18/PUU-V/2007, terpidana pelanggaran HAM berat Timor Timur dipidana berdasarkan putusan kasasi MA Nomor 06 K/PID.HAM AD HOC/2005 tanggal 13 Maret 2006.

Putusan Nomor 065/PUU-II/2004, h. 38.

Ibid. h. 35

85 Putusan Nomor 18/PUU-V/2007, paragraf [3.27]

86 Dibentuk berdasarkan Undang-Undang Nomor 27 Tahun 2004 tentang Komisi Kebenaran dan Rekonsiliasi. 
yang terdiri dari beberapa lembaga swadaya masyarakat, seperti Lembaga Studi dan Advokasi Masyarakat (ELSAM), Komisi untuk Orang Hilang dan Korban Kekerasan (Kontras) m dan Inisiatif Masyarakat Partisipatif untuk Transisi Berkeadilan (Imparsial). Dalam putusannya, MK menyorot aturan menjadi jiwa dalam UU KKR yaitu mengenai mekanisme pemberian kompensasi dan rehabilitasi sebagai cara menuju rekonsiliasi. ${ }^{87}$ MK menilai bahwa pemberian kompensasi dan rehabilitasi yang digantungkan pada keberhasilan permohonan amnesti kepada Presiden adalah dua pendekatan yang tidak saling terkait. Amnesti adalah hak prerogatif Presiden. Pengabulan atau penolakan amnesti adalah hak subyektif Presiden. Sedangkan, pemberian kompensasi dan rehabilitasi dalam upaya rekonsiliasi sejatinya ditekankan pada korban dan bukan pada keberhasilan permohonan amnesti. Oleh karenanya, aturan pemberian kompensasi dan rehabilitasi yang didasarkan pada amnesti merupakan aturan yang inkonstitusional. Selanjutnya, karena aturan ini merupakan jiwa yang menaungi seluruh aturan dalam UU KKR maka MK membatalkan keberlakuan UU KKR secara keseluruhan.

\section{e. Pendefinisian Jati Diri Bangsa}

Di berbagai negara, lembaga peradilan bergelut dengan pertanyaan-pertanyaan politik yang menentukan jati diri suatu bangsa. Di Turki, misalnya, mahkamah konstitusi memberikan penafsiran resmi mengenai prinsip sekularisme (dalam bahasa Turki disebut laiklik) yang diadopsi dalam konstitusi negara. ${ }^{88}$ Di negaranegara yang mayoritas Islam, pertanyaan mengenai kedudukan syariah dalam hukum negara seringkali diajukan pada muka peradilan. Di Pakistan persoalan kedudukan syariah dalam negara ini dipertimbangkan dalam putusan Mahkamah Agung tahun 2002.89 Begitu pula di Mesir, mahkamah konstitusi Mesir terlibat sangat dalam mengenai identitas nasional Mesir ketika memeriksa perkara mengenai larangan mengenakan hijab (niqab) ditahun 1996.9 ${ }^{90}$ Selain itu, penting juga untuk dikutip mengenai Putusan yang dijatuhkan oleh Mahkamah Agung Kanada dalam hal penetapan status bilingualism dan masa depan negara bagian Quebec dalam hubungannya dengan negara federal Kanada. ${ }^{91}$

Di Indonesia belum ada putusan MK yang memiliki kandungan penentuan jati diri bangsa sebesar putusan-putusan yang telah dikutip diatas. Salah satu putusan yang memiliki obyek perkara berkaitan dengan bangsa adalah ketika MK memutus mengenai kedudukan Pancasila. ${ }^{92}$ Akan tetapi, putusan MK hanya berkutat persoalan semantik mengenai apakah Pancasila itu dapat dikatakan sebagai "pilar" berbangsa padahal Pancasila adalah "dasar"

\footnotetext{
87 Putusan Nomor 006/PUU-IV/2006, hal 120-122.

88 Turkish Constitutional Court Decision, No. Perkara: 1970/53, No. Putusan: 1971/76, Tanggal Putusan 21 Oktober 1971.

89 Constitution Petition No.15 of 2002, Jamaat-e-Islami Pakistan Mansoora v. General Pervez Musharraf.

90 Nathan J. Brown \& Clark B. Lombardi, Translation: The Supreme Constitutional Court of Egypt on Islamic Law, Veiling and Civil Rights: An Annotated Translation of Supreme Constitutional Court of Egypt Case No. 8 of Judicial Year 17 (May 18, 1996);

Lihat juga diskusi mendalamnya pada Luna Droubi, "The Constitutionality of the Niqab Ban in Egypt: A Symbol of Egypt's Struggle for a Legal Identity", New York Law School Law Review, (Volume 56 | 2011/12) , hlm. 687-709.

91 Reference re Secession of Quebec, [1998] 2 S.C.R. 217.

92 Putusan Nomor 100/PUU-XI/2013, tanggal 3 April 2014.
} 
negara. Salah satu butir yang dapat dikutip dalam putusan MK adalah pertimbangan bahwa "... Pancasila memiliki kedudukan yang tersendiri dalam kerangka berpikir bangsa dan negara Indonesia yaitu disamping sebagai dasar negara, juga sebagai dasar filosofi negara, norma fundamental negara, ideologi negara, cita hukum negara." ${ }^{93}$ Sayangnya, pertimbangan MK tidak menguraikan lebih lanjut apa yang dimaksud dengan konsep-konsep tersebut dan mengapa MK memandang perlu untuk membedakan konsep-konsep tersebut. MK dalam pertimbangannya langsung pada kesimpulan “...menempatkan Pancasila sebagai salah satu pilar dapat mengaburkan posisi Pancasila dalam makna yang demikian itu." ${ }^{94}$

\section{Penutup}

Perkembangan praktek ketatanegaraan sangatlah dinamis. Pemahaman atas prinsip pemisahan kekuasaan tidak dapat dimaknai secara kaku dimana lembaga-lembaga negara terutama para pemegang tiga cabang kekuasaan terpisah antara satu dengan yang lain. Praktek menunjukkan bahwa batas-batas pemisah antara pemegang cabang kekuasaan semakin memudar. Salah satunya adalah dalam pola hubungan legislatif dengan yudisial. Penelitian ini menunjukkan bahwa dengan diadopsinya kewenangan pengujian UU terhadap UUD, MK telah menembus batas prinsip pemisahan kekuasaan. MK juga menjalankan fungsi legislasi dengan bertindak sebagai positive legislator. Beragam putusan yang dikutip dalam penelitian ini telah menunjukkan fakta bahwa MK terlibat dalam fungsi legislasi. Kadar politis dalam putusan judicial review yang dijatuhkan MK juga tidak dapat dinilai sebagai politik rendah (lowpolitics) karena putusan MK menentukan arah perjalanan bangsa Indonesia. Kandungan dalam beberapa putusan MK bernilai sangat strategis dan mengacu pada istilah yang dikemukakan Ran Hirschl sebagai mega-politics.

Fenomena ini bukanlah suatu keadaan unik yang hanya terjadi di Indonesia. Berbagai negara juga mengalami fenomena serupa, terutama di negara-negara dimana lembaga peradilannya mengadopsi kewenangan judicial review. Legitimasi konseptual juga telah ditawarkan oleh para ahli hukum dan politik dengan merumuskan konsep judicialisation of politics. Dimasa mendatang, lembaga peradilan akan semakin cenderung terlibat dalam perkaraperkara menyangkut proses pengambilan kebijakan yang menyangkut kepentingan orang banyak dimana awalnya proses itu merupakan kewenangan eksklusif dari legislatif. Sisi positifnya adalah warga negara memiliki saluran untuk mengekspresikan ketidaksetujuannya atas produk legislasi melalui dialog konstitusional yang difasilitasi oleh mahkamah konstitusi.

\section{DAFTAR PUSTAKA}

\section{Buku}

Asshiddiqie, Jimly, Konstitusi dan Konstitusionalisme Indonesia, (Jakarta: Konpress, 2006) cet. Kedua. Asshiddiqie, Jimly, Pergumulan Peran Pemerintah dan Parlemen dalam Sejarah: Telaah Perbandingan Konstitusi berbagai Negara, (Jakarta: UI Press, 1996)

Dressel, Bjoern (ed.), The Judisialization of Politics in Asia, (Routledge Law in Asia, 2012)

Isra, Saldi, Pergeseran Fungsi Legislasi: Menguatnya Model Legislasi Parlementer dalam Sistem

Putusan Nomor 100/PUU-XI/2013, paragraf [3.12].

Ibid. 
Presidensial Indonesia, cet. 1 (Jakarta: PT Rajagrafindo Persada, 2010)

Kelsen, Hans, Teori umum Hukum dan Negara, cet. 1, (Jakarta: Bee Media, 2007)

Mahfud MD, Moh., Politik Hukum di Indonesia, cet.4 (Jakarta: Rajawali Pers, 2011)

Rahardjo, Satjipto, Beberapa Pemikiran tentang Ancangan antar Disiplin dalam Pembinaan Hukum Nasional, (Bandung: Sinar Baru, 1985)

\section{Makalah/Artikel/Laporan/Hasil Penelitian}

Asyari, Syukri, Meyrinda Hilipito dan Moh. Mahrus Ali, "Model dan Implementasi Putusan Mahkamah Konstitusi dalam Pengujian UndangUndang (Studi Putusan Tahun 2003-2012)", Jakarta: Pusat P4TIK MK, 2013.

Barboza, Estefânia Maria De Queiroz dan Katya Kozicki, "Judicialization of Politics and the Judicial Review of Public Policies by the Brazilian Supreme Court", Revista Direito GV, Vol. 8, no. 1, 2012, hal 59-85

Bisariyadi, Yudisialisasi Politik dan Sikap Menahandiri: Peran Mahkamah Konstitusi dalam menguji Undang-Undang, Jurnal Konstitusi, Vol. 12, No. 3, 2015

Droubi, Luna, "The Constitutionality of the Niqab Ban in Egypt: A Symbol of Egypt's Struggle for a Legal Identity", New York Law School Law Review, VOLUME 56 | 2011/12, h. 687-709.

Edelman, Martin, "The Judicialization of Politics in Israel." International Political Science Review, Vol. 15, Issue 2, 1994, hal. 177-186.

Friedman, Barry, "The Politics of Judicial Review," Texas Law Review, Vol. 84, No. 2, December 2005.

Hirschl, Ran, "The Judicialization of Mega-Politics and the Rise of Political Courts". Annual Review of Political Science, Vol. 11, 2008. diunduh SSRN: http://ssrn.com/abstract=1138008

Hirschl, Ran, "The New Constitution and the Judicialization of Pure Politics Worldwide", Fordham Law Review, Vol. 75, Issue 2, 2006, hal. 721-754.

Landfried, Christine, "The Judicialization of Politics in Germany," International Political Science Review, Vol. 15, Issue 2, 1994, hal. 113-124.

Mahkamah Agung, Laporan Tahunan Mahkamah Agung Republik Indonesia 2013.

Moustafa, Tamir, "Law versus the State: The Judicialization of Politics in Egypt", Law \& Social Inquiry, Vol. 28, Issue 4, 2003, hal 883-930.
Park, Jonghyun, "The Judicialization of Politics in Korea," Asian-Pacific Law \& Policy Journal, Vol. 10, Number 1, 2008.

Solikin, M. Nur,, dkk, "Laporan Kajian tentang Implementasi Pengawasan Perda oleh Pemerintah dan Mahkamah Agung", Pusat Studi Hukum dan Kebijakan Indonesia: 2011,

Stone Sweet, Alec, "The Politics of Constitutional Review in France and Europe," International Journal of Constitutional Law, Vol. 5, Issue 1, January 2007. h. 69-92

Tate, C. Neal, "The Judicialization of Politics in the Philippines and Southeast Asia," International Political Science Review, vol. 15, no. 2, April 1994, hal. 187-197

Ten Kate, Jan dan PeterJ. Van Koppen, "Judicialization of Politics in the Netherlands: Towards a Form of Judicial Review." International Political Science Review, Vol. 15, Issue 2, 1994, hal 143-151.

\section{Peraturan}

Putusan Nomor 011-017/PUU-I/2003 bertanggal 24 Februari 2004 tentang Pengujian Pasal 60 huruf $g$ Undang-Undang Nomor 12 Tahun 2003 tentang Pemilihan Umum Anggota Dewan Perwakilan Rakyat, Dewan Perwakilan Daerah, dan Dewan Perwakilan Rakyat Daerah.

Putusan Nomor 10/PUU-VI/2008 bertanggal 1 Juli 2008 tentang pengujian Pasal 12 huruf $c$ Undang-Undang Nomor 10 Tahun 2008 tentang Pemilihan Umum Anggota Dewan Perwakilan Rakyat, Dewan Perwakilan Daerah, dan Dewan Perwakilan Rakyat Daerah (UU Pemilu DPR, DPD, dan DPRD).

Putusan Nomor 4/PUU-VII/2009 bertanggal 24 Maret 2009 tentang pengujian Pasal 12 huruf g dan Pasal 50 ayat (1) huruf g UU Pemilu DPR, DPD, dan DPRD dan Pasal 58 huruf $f$ UU Pemda.

Putusan Nomor 012/PUU-III/2005 bertanggal 19 Oktober 2005 perihal Pengujian UndangUndang Nomor 36 Tahun 2004 tentang Anggaran Pendapatan dan Belanja Negara Tahun Anggaran 2005

Putusan Nomor 026/PUU-III/2005 bertanggal 22 Maret 2006 perihal Pengujian Undang-Undang Nomor 13 Tahun 2005 tentang Anggaran Pendapatan dan Belanja Negara Tahun Anggaran 2006

Putusan Nomor 026/PUU-IV/2006 perihal Pengujian Undang-Undang Nomor 18 Tahun 2006 tentang 
Anggaran Pendapatan dan Belanja Negara Tahun Anggaran 2007.

Putusan Nomor 13/PUU-VI/2008 bertanggal 13 Agustus 2008tentang Pengujian Undang-Undang Nomor 16 Tahun 2008 tentang Perubahan Atas Undang-Undang Nomor 45 Tahun 2007 tentang Anggaran Pendapatan dan Belanja Negara Tahun Anggaran 2008 (UU APBN 2008)
Turkish Constitutional Court Decision, No. Perkara: 1970/53, No. Putusan: 1971/76, Tanggal Putusan 21 Oktober 1971.

Constitution Petition No.15 of 2002, Jamaat-e-Islami Pakistan Mansoora v. General Pervez Musharraf Reference re Secession of Quebec, [1998] 2 S.C.R. 217

Kilbourn v. Thompson, 103 US 168 (1880) 